\title{
Mellem Klosteret og Verden
}

\author{
Armand-Jean de Rancé (1626-1700) \\ Professor, dr.theol. \\ Mette Birkedal Bruun, Københavns Universitet
}

\begin{abstract}
The article presents Armand-Jean de Rancés reform of the Cistercian abbey of La Trappe. It positions Rancés ascetic programme within the wider devotional culture of seventeenth-century France, and explores in three registers the inherent dynamic between withdrawal from the world and engagement with the world. The first register concerns the abbot's biography, the argument being that the familial, societal and ecclesiastical circles inhabited by Rancé before and after his conversion are more closely connected than has been traditionally seen. The second is dedicated to the position of La Trappe in contemporary society and a discussion of the continuous traffic across the monastic wall of texts, guests, rumours and myths. The third involves an examination of the role of withdrawal and engagement in Rancé's reform and its ascetic programme, showing how the abbot expounds the central notion of solitude as a place, a condition and a strategy. The article presents key insights from the author's doctoral thesis, which was defended at the University of Copenhagen in June 2017.
\end{abstract}

Keywords: Armand-Jean de Rancé - withdrawal - engagement - solitude - devotion - La Trappe - monastic reform - early modern France.

\section{Prolog}

I 1693 besøgte Philippe af Orléans, Solkongens bror og kendt som "Monsieur", cistercienserklosteret La Trappe i Normandiet. Prinsen og hans følge af 50 officerer blev modtaget af en procession af munke og deltog i vesperen, og bagefter spiste de middag med abbeden, Armand-Jean de Rancé. ${ }^{1}$ Prinsen tog et stykke af det grove trappistbrød med hjem til Versailles, hvor hoffolkene lod det gå fra hånd til hånd under behørig beundring. Hertuginden af Guise, Ludvig XIVs kusi-

1. Krailsheimer daterer prinsens besøg til 11. juli 1693; Abbé de Rancé: Correspondance, red. A.J. Krailsheimer, 4 bd. (Paris: Les Éditions du Cerf og Cîteaux: Commentarii cistercienses 1993), 4: 267. Se også Jacques Marsollier, La vie de Dom Armand-Jean le Bouthillier de Rancé, 2 bd. (Paris: Jean de Nully 1703), 2: 138 og Pierre le Nain, La vie du reverend pere Dom Armand Jean le Bouthillier de Rancé, 3 bd. (s.l.: s.n. 1715), 2: 302f. 
ne, som selv var en hyppig gæst på La Trappe, fortalte siden Rancé om optrinnet i et brev, og han svarede, at, ja, Monsieur havde virkelig været begejstret for besøget, og det gjorde et dybt åndeligt indtryk. ${ }^{2}$ Ifølge en samtidig kilde havde prinsen endda forsikret abbeden om, at livet ved La Trappe var opbyggeligt ikke blot for Frankrig, men for hele Europa, og at hoffet ville have gavn af at understøtte det (Le Nain 1715, 2, s. 303). Mens det franske hof beundrede grovbrødet fra La Trappe og det forunderligt strenge liv, som blev ført i denne fjerne udørk $150 \mathrm{~km}$ vest for Paris, gik en hungersnød over landet og dræbte to mio. mennesker. ${ }^{3}$

Beretningen om Philippe af Orleáns' besøg på La Trappe hører nok til i grænselandet mellem myte og virkelighed, ${ }^{4}$ men den er typisk for den aura, som i det sene 1600-tals Frankrig omgav Rancé og hans trappist-reform. Der er de asketiske munke i deres ødemark og aristokraterne, som besøger dem; der er det grove brød som symbol på en radikal asketisk fromhed; endelig er der de breve og beskrivelser, som krydser frem og tilbage over klostermuren og kommenterer begivenheden. Dette kompleks er genstanden for den disputats, hvis anliggende jeg her præsenterer. ${ }^{5}$

2. Louis Dubois, Histoire de l'Abbé de Rancé, 2 bd. (Paris: Ambroise Bray 1866), 2 : 393. Brevet fra Rancé til Mme de Guise er dateret 23. august 1693; Rancé (1993), 4: $266 f$.

3. For de brede masser var 1600-tallets Frankrig præget af dyb nød; Jean-Pierre Poussou, "Disettes et famines", Dictionnaire de l'Ancien Régime, red. Lucien Bély (Paris: Quadrige/PUF 1996), 415.

4. Dens troværdighed understreges dog i A.J. Krailsheimer, Armand-Jean de Rancé: Abbot of La Trappe (Oxford: Clarendon Press 1974), 85.

5. Mette Birkedal Bruun, The Unfamiliar Familiar: Armand-Jean de Rancé (16261700) between Withdrawal and Engagement (København: Publikationer fra Det Teologiske Fakultet 2017). Forsvaret fandt sted 30. juni 2017, og bedømmelsesudvalget bestod af Prof. emerita Barbara B. Diefendorf, Department of History, Boston University, Maître de conférences Anne Régent-Susini, Université Paris III-Sorbonne nouvelle og lektor emeritus Nils Holger Petersen, Københavns Universitet (formand). Den forskning, der er blevet fremlagt i disputatsen, er blevet gennemført ved Danmarks Grundforskningsfonds Center for Studiet af Kulturarven fra Middelalderens Ritualer under ledelse af Nils Holger Petersen, hvor jeg var ansat 2002-2009, og i forbindelse med det kollektive forskningsprojekt SOLITUDES: Withdrawal and Engagement in the long Seventeenth Century (2013-2017), finansieret af Det europæiske Forskningsråd, ERC (313397 - MOS). Jeg skylder mine kolleger i begge sammenhænge varm tak for givende diskussioner undervejs. Det gælder især Lars Nørgaard, Kristian Mejrup, Eelco Nagelsmit og Sven Rune Havsteen samt Nils Holger Petersen og Martin Wangsgaard-Jürgensen. Også Søren Frank Jensen skylder jeg tak. Disputatsens indsigter vedrørende religiøst motiveret tilbagetrækning fra verden i den tidlig moderne periode er en grundsten i den forskning, der nu foregår ved Danmarks Grundforskningsfonds Centre for Privacy Studies (DRNF 138). 
Armand-Jean le Bouthillier de Rancé (1626-1700) stammede fra en familie af fremtrædende embedsmænd. Han blev tidligt bestemt til en kirkelig løbebane, og som blot 11-årig arvede han embedet som abbed in commendam for fem forskellige klostre fra forskellige ordener, herunder cistercienserklosteret La Trappe. ${ }^{6}$ I 1654 blev Rancé teologisk doktor fra Sorbonne. Han rustede sig til præstegerningen, fik erfaring som prædikant og førte teologiske samtaler; sideløbende passede han sine jagtudflugter, sine besøg i kulturelle saloner og sin forbindelse til den notorisk forførende hertuginde af Montbazon, Marie d'Avaugour (1610/12-1657). Han var udset til at efterfølge sin onkel, ærkebiskoppen af Tours Victor Bouthillier (1596-1670), men da familien faldt $\mathrm{i}$ unåde under førsteministeren kardinal Mazarin (i embede 1642-1661), falmede dét perspektiv. Til gengæld pegede udnævnelsen som kapellan for Ludvig XIIIs bror, Gaston af Orléans (1608-1660) i 1656 i retning af en solid kirkelig karriere. Men så skiftede Rancé spor. Montbazons død i 1657 og Gastons død i 1660 var formodentlig afgørende, den politiske modvind havde måske også betydning. Selv sagde han senere, at han ikke fandt dét, han søgte, i verden. ${ }^{7}$ Fra 1657 trak Rancé sig gradvist tilbage fra det sociale liv. Hans omvendelsesproces kulminerede i et cisterciensisk noviciat og hans indsættelse som regulær abbed for La Trappe i 1663 . Her blev han resten af sit liv og gennemførte en streng reform centreret om bod, askese, tavshed og fuldstændig afsondring fra verden.

Det trappistiske reformprogram gav genlyd uden for klosterets mure. Fromme og nysgerrige læsere kastede sig over piratkopier af klosterets konstitutioner, og abbedens skrifter cirkulerede blandt medlemmer af den fromme overklasse. Det gjaldt både hans 1000-siders manifest om klosterlivets hellighed og forpligtelser (1683), ${ }^{8}$ den kommenterede oversættelse af Benedikts Regel (1689), ${ }^{9}$ hans oversættelse fra græsk af Dorotheos af Gazas (ca. 510-580) instruktioner

\footnotetext{
6. Abbeder in commendam var tidens mest udbredte form for klosterledelse; ordningen indebar, at abbeden var klosterets formelle leder og modtog indtægter fra det uden at bo på stedet og uden nødvendigvis at have administrative eller religiøse ambitioner. Disse embeder blev handlet og gik i arv på samme måde som andre poster i tiden; Philippe Loupès, "Commende", Dictionnaire de l'Ancien Régime, red. Lucien Bély (Paris: Quadrige/PUF 1996), 290---91. Ifølge Loupès blev 84\% af 1600-tallets franske klostre ledet in commendam.

7. Brev til Mme de Lafayette af 22. november 1686; Rancé (1993), 3: 405.

8. Rancé, De la sainteté et des devoirs de la vie monastique, 2 bd. (Paris: François Muguet 1683).

9. Rancé, La Régle de saint Benoist nouvellement traduite, \& expliquée selon son veritable esprit, 2 bd. (Paris: François Muguet 1689).
} 
(1686), ${ }^{10}$ samlingerne af trappist-biografier ${ }^{11}$ samt de fire bind prædikener (1698). ${ }^{12}$ Først og fremmest blev abbeden selv hovedperson i en fortælling om radikal omvendelse og indædt askese, og hans biografi gav lige så meget genlyd som hans skrifter.

Andre har forsket i Rancé, ${ }^{13}$ men ingen har tidligere gennemført en systematisk analyse af forholdet mellem hans asketiske program og tidens religiøse kultur. Afhandlingen er et detailstudie af et monastisk fænomen i dets historiske kontekst. Den bidrager til forskningen i cistercienserordenen og den tidlig moderne klosterbevægelse, men viser også klostrenes plads i 1600-tallets Frankrigs religiøse og til dels kulturelle landskab gennem et konkret eksempel. Dermed udfordrer afhandlingen den markante grænse mellem forskning i hhv. kulturog fromhedsliv i le grand siècle. ${ }^{14}$ Afhandlingens overordnede mål er at behandle fordringen om at være i verden uden at være af verden, som den kommer til udtryk i en bestemt historisk kontekst. Rancé påkalder sig særlig interesse, fordi han på den ene side kræver, at trappisterne skal være fuldstændigt afsondret fra verden, men på den anden side selv interagerer intenst med tidens fromme overklasse. Dette paradoks giver anledning til en undersøgelse af dynamikken mellem de tilsyneladende modsætninger afsondring og engagement. ${ }^{15}$ Det er

10. Rancé, Instruction sur la mort de Dom Muce, Religieux de l'abbaye de la Trappe (Paris: François Muguet 1690).

11. Se fx Rancé, Relations de la mort de quelques religieux de l'abbaye de la Trappe, 2 bd. (Paris: Florentin \& Pierre Delaulne 1696).

12. De eneste Rancé-tekster, der er kommet i en moderne udgave, er de fire bind breve udgivet af Krailsheimer i Rancé (1993).

13. De vigtigste er David N. Bell, Understanding Rancé: The Spirituality of the Abbot of La Trappe in Context (Kalamazoo: Cistercian Publications 2005), Krailsheimer (1974) og Chrysogonus Waddell, "The Cistercian Dimension of the Reform of La Trappe", Cistercians in the Late Middle Ages, red. E. Rozanne Elder (Kalamazoo: Cistercian Publications 1981), 102-61.

14. Denne adskillelse håndhæves fra begge sider. For en fromhedshistorisk vinkel, der isolerer Rancé fra samtidig indflydelse, se fx Lucien Aubry, "Rancé's Spirituality", Cistercian Studies Quaterly 35.1 (2000), 47-54; for en kulturhistorisk vinkel, der adskiller de to, fx Beugnots kortlægning af, hvad begreberne retraite (afsondring) og solitude (ensomhed, afsondring, vildmark) betyder for hhv. "de åndelige" og "de andre" ("les spirituels" / "les autres"); Bernard Beugnot, "Loisir, retraite, solitude", Le loisir lettré à l'âge classique, red. Marc Fumaroli, Philippe-Joseph Salazar \& Emmanuel Bury (Geneva: Droz 1996), 173-95.

15. Begreberne "afsondring" og "engagement" tilhører ikke samme historiske register. Termerne retraite og solitude optræder hyppigt hos Rancé og hans samtidige. Men i 1600-tallet angår termen engagement især formel og lovmæssig tilknytning, og ordet bruges om et løfte eller en forpligtelse $\mathrm{fx}$ i forbindelse med monastisk profession; se fx Conference pour le Dimanche de la Quinquagesime i Rancé, Conferences ou Instructions sur les epitres et evangiles des dimanches et principales festes de l'année, Et sur les Vêtures \& Professions Religieuses, 4 bd. (Paris: Florentin \& Pierre Delaulne, 1698) 2: 125 . I afhandlingen betegner "engagement" Rancés interaktion med ver- 
en dynamik, som udfoldes i flere dimensioner, og jeg har angrebet emnet fra tre forskellige synsvinkler, der fokuserer på hhv. biografi, kommunikation og asketisk program.

\section{Rancés verden}

Afhandlingens første del, Context, etablerer den historiske ramme (Bruun 2017, 47-206). Her trækkes der tråde på tværs af abbedens omvendelse i en udfordring af den dramaturgisk bekvemme sondring mellem et dybt verdsligt for og et dybt religiøst efter. Bouthillier-familien tilhørte inderkredsen omkring Frankrigs førsteminister, kardinal Richelieu (1585-1642). ${ }^{16}$ Rancés onkler på fædrene side talte en statssekretær og to biskopper, og hans far, Denis Bouthillier, var sekretær for kongens mor, Marie de Medicis. Det er især slægtens politiske aktiviteter, der har påkaldt sig interesse, men den er også præget af tidens fromme strømninger. Rancés bedstemor, Claude de Machéco (d. 1630) endte sit liv i Visitationsordenen, ${ }^{17}$ onklerne havde nære bånd til både præsteordenen Oratorianerne og kredsen omkring Port-Royal, ${ }^{18}$ og Rancés tante, Marie de Bragelogne (1590-1673) introducerede ham til den ledende Port-Royal tilhænger Robert Arnauld d'Andilly (1589-1674), som blev hans mentor under omvendelsen. ${ }^{19}$ Heller ikke de sociale kredse, Rancé færdedes i før sin omvendelse, var rent verdslige. Salonen i Hôtel de Nevers talte mellem

\footnotetext{
den uden for La Trappe gennem konkrete korrespondancer og aktiviteter, men også hans forbundethed med tidens religiøse og æstetiske normer.

16. Yves Le Guillou, Les Bouthillier, de l'avocat au surintendant (ca 1540-1652): histoire d'une ascension sociale et formation d'une fortune (Paris: École nationale des chartes 1997), 128; Joseph Bergin, Cardinal Richelieu: Power and the Pursuit of Wealth (New Haven \& London: Yale University Press 1985), 182.

17. Françoise-Madeleine de Chaugy, Les vies de VIII. venerables veuves religieuses de l'ordre de la Visitation (Annecy: Jacques Clerc 1659), 65-68.

18. Rancés farbror Sébastien Bouthillier (1580-1625), biskop af Aire, der døde året før Rancés fødsel, var en nær ven af Saint-Cyran og Arnauld d'Andilly, to hovedfigurer i den tidlige jansenisme, den populære betegnelse for den strengt augustinske bevægelse, der opstod omkring klosteret Port-Royal; Claude Lancelot, Mémoires touchant la vie de Monsieur de S. Cyran, 2 bd. (Cologne: La Compagnie 1738), 2: 267; Jean Orcibal, Jean Duvergier de Hauranne: Abbé de Saint-Cyran et son Temps, Les origines du Jansénisme, bd. 2 (Louvain: Bureaux de la revue/Paris: Librairie philosophique J. Vrin 1947), 224, note 5-6 og 643.

19. Se Rancés brev til d'Andilly 19. juni 1673 i anledning af tantens død; Rancé (1993), 1: 561. Se også hans breve skrevet fra Marie de Bragelognes hus i Pont-surSeine til d'Andilly fra 16. juni 1659 og til Louise Rogier fra 1. juni 1660; Rancé (1993), 1: $124 f$ og 149f.
} 
diplomater og kulturpersoner også gejstlige samt førende tilhængere af Port-Royal, og samtidige beretter, at Rancé var blandt en udvalgt kreds af tilhørere, der i Hôtel de Nevers overværede oplæsningen af et udkast til Blaise Pascals (1623-1662) sjette provinsbrev, som forfatteren havde sendt til husets frue for at få hendes gæsters bedømmelse. ${ }^{20}$

Rancé bevarede forbindelsen til den verden efter omvendelsen. Det er biografisk pikant, at den afdøde elskerinde Mme de Montbazons søn og to søstre optræder i abbedens korrespondance, men vigtigt, at brevene viser Rancé i sjælesørgerens rolle. ${ }^{21}$ Også gæster fra Hôtel de Nevers holdt han kontakt med, og værtinden, Mme de Guénégaud besøgte formentlig La Trappe et par gange, efter hendes tidligere gæst var blevet abbed der (Bruun 2017, 120-23). ${ }^{22}$ Rancés omvendelse betød heller ikke, at han afskar forbindelsen til søskende, niecer og nevøer; hans interesse gjaldt dog først og fremmest dem i familiekredsen, der også gik klostervejen. ${ }^{23}$ Rancés før-monastiske liv er altså ikke uden fromme aspirationer og hans klosterliv ikke uden forbindelse til fortiden. Når vi forfølger bekendt- og slægtsskaber gennem hans breve, begynder vi at se, hvordan tidlige relationer levede videre ind i Rancés klosterliv, og hvordan den åndelige vejledning, han udøvede som abbed, også omfattede mennesker, han havde kendt før sin omvendelse, eller som tilhørte kredse, der lignede hans før-monastiske liv.

Rancé blev først cistercienser midt i livet, men han tilhørte det kirkelige hierarki, fra han var ni år gammel. Det var hverken religiøst eller institutionelt oprør, der drev hans tilbagetrækning fra verden. Han betragtede sine reformbestræbelser som et bidrag til Kirkens arbejde, og hans breve til biskopper viser, i hvor høj grad hans monastiske program lå i forlængelse af samtidige kirkelige lederes reformindsats over hele Frankrig og var inspireret af gejstlige, han i flere tilfælde

20. René Rapin, Mémoires du P. René Rapin de la compagnie de Jésus sur l'église, la ville et le jansénisme, red. Léon Aubineau, 3 bd. (Paris: Gaume Frères et J. Duprey 1865), 1: 389 og 403-5 et passim. For oplæsningen af Pascal, se Rapin (1865), 2: $367 f$.

21. Især er der hyppige breve til Montbazons lillesøster Catherine-Françoise d'Avaugour de Bretagne, Mlle de Vertus (1615-92); ifølge Krailsheimer skrev Rancé formodentlig til Vertus en gang om måneden; Krailsheimer (1974), 280.

22. For Mme du Plessis-Guénégauds besøg på La Trappe i 1673 og 1675, se bl.a. Rancés breve til d'Andilly fra 7. juni og 2. juli 1673; Rancé (1993), 1: 554 og 563 og hans brev til Gilbert de Choiseul fra april 1675; Rancé (1993), 1: 665-67. Se også Rancés brev til Mme du Plessis-Guénégaud om mandens død fra slutningen af marts 1676; Rancé (1993), 2: 40.

23. Rancés ældre søster var cisterciensernonne, og den yngre var franciskaner. Et særligt nært forhold havde Rancé til sin niece Louise-Henriette (c. 1646-88), som trådte ind i Visitationsordenen samtidigt med hans omvendelse. 
havde kendt siden sin ungdom. ${ }^{24}$ Rancé var generelt disse biskoppers ligemand i social baggrund, uddannelse og i nogen grad aktionsradius. Da han med erklæret fornøjelse under sin omvendelse læste du Perrons Réplique à la réponse du sérénissime roi de la Grande-Bretagne (1620), beskrev han den som en vejledning i de ting, han måtte tilegne sig for at blive abbed. ${ }^{25} \mathrm{Du}$ Perrons værk er en veritabel håndbog i tridentinsk ekklesiologi, og læseindtrykket klinger muligvis med, når Rancé ved begyndelsen af sit noviciat erklærer, at han vil "bruge resten af mit liv på bod og på at arbejde for genetableringen af Guds ære på det sted, han synes at have anvist mig, i overensstemmelse med Kirkens formål, som blev udlagt så tydeligt ved koncilet i Trent." ${ }^{26}$

\section{Udveksling mellem verden og klosteret}

Afhandlingens anden del, Osmoses, fokuserer på den mangeartede trafik mellem La Trappe og det omgivende samfund. Tekster, gæster, rygter og myter krydsede klosterets mur i en lind strøm (Bruun 2017, 207-386). Abbeden var ikke blind for formidlingens betydning. En tekst som hovedværket De la sainteté et des devoirs de la vie monastique (1683), som han hævdede kun var skrevet til munke, blev udsmykket med vignetter og blomsterornamentik, som gør det klart, at han havde et bredere publikum i tankerne. Men Rancés breve og skrifter blev også, som mange andre tekster i 1600-tallets Frankrig, givet videre og endog trykt uden hans accept. ${ }^{27}$ Hvad enten han ville det eller ej, skrev han potentielt for verdens øjne, så snart han satte

24. Se Paul Broutin, La réforme pastorale en France au XVII siècle, 2 bd. (Tournai: Desclée \& co. 1956). Rancés to nærmeste venner, som begge havde rødder i hans liv før La Trappe, var hhv. den jansenistisk orienterede Henri de Barillon (1639-99), biskop af Luçon (fra 1671), og Étienne le Camus (1632-1707), biskop af Grenoble (fra 1671) og kardinal (fra 1686). Se fx det udaterede brev fra le Camus til Barillon; Étienne Le Camus, Lettres du Cardinal le Camus: Évêque et Prince de Grenoble (1632-1707), red. P. Ingold (Paris: Alphonse Picard 1892), 321.

25. Brev til d'Andilly af 14. december 1658; Rancé (1993), 1: 113f; se også brevet til d'Andilly 24. oktober 1658; Rancé (1993), 1: 109 og Krailsheimers note, Rancé (1993), 1: 110.

26. Brev til Nicolas Pavillon af 30. maj 1663; Rancé (1993), 1: 210: "consacrer le reste de ma vie à la pénitence, et de travailler au rétablissement de la gloire de Dieu dans le lieu auquel il paraissait qu'il m'avait appliqué, suivant les désirs et les intentions de l'Église qui s'est si clairement expliquée dans le concile de Trent". Rancé fortæller om Perron i et brev til d'Andilly af 14. december 1658; Rancé (1993), 1: 113f; se også brevet til d'Andilly af 24. oktober 1658; Rancé (1993), 1: 109 og Krailsheimers kommentar; Rancé (1993), 1: 110.

27. Se fx brevet til Jean Favier fra 3. oktober 1675; Rancé (1993), 1: 700. 
pennen til papiret for at formulere sit ideal om tilbagetrækning. Uden for murene optræder Rancé i breve, pamfletter, satirer, hyldest- og spottedigte, billeder og medaljer. Et kuriøst eksempel på samtidens repræsentation af Rancé er abbedens optræden i selskabslegen bouts rimés, "enderim". Legen går ud på, at deltagerne får udstukket et sæt umage enderim og derefter skal forfatte vers over dem. ${ }^{28}$ Angiveligt holdt "en herre fra provinsen" i 1682 en middag, hvor han foreslog syv par enderim, der omfattede så uens størrelser som "snegl" / "stok" (escargot - ragot) og "depravere" / "rødbede" (déprave - rave). Fire gæster tog imod udfordringen, men for bedre at kunne vise deres talent bad de værten om et tema for de poetiske udfoldelser. Han gav dem "abbeden af La Trappe", og dagen efter lå der fire sonnetter, hvoraf en med særligt vid udfoldede sig om abbeden, der boede i et hul som en snegl og disciplinerede sin krop med en stok, som ikke var plaget af de lyster, der depraverer andre, og hvis måltid var en rødbede. ${ }^{29}$ Det er værd at bemærke dateringen. I 1682 havde Rancé været abbed i næsten tyve år, og femogtyve år var gået siden Montbazons død. Men det var først året efter, han igen for alvor skulle gøre sig bemærket med hovedværket De la sainteté et des devoirs de la vie monastique, så selv om episoden nok skal tages med et gran salt, antyder beretningen, at Rancé var lidt af et fænomen, og at han var til stede i den dannede overklasses bevidsthed uden selv at agere.

Andre gange var han langt mere aktiv. Han kastede sig ud i en retorisk brutal strid om monastiske studier. Rancé mente, at munke skulle holde sig fra lærd arbejde, fordi det fremmer stolthed og nysgerrighed. Den maurinske gren af benediktinerordenen, der $\mathrm{i}$ 1600-tallets slutning med centrum i pariserklosteret Saint-Germaindes-Prés arbejdede intenst med tekstkritiske udgaver af middelaldertekster, var ikke overraskende uenig. Rancés stejle holdning gav ham mange fjender. ${ }^{30}$ En lidt mere fredelig rolle spillede han i oprettelsen af en pigeskole i La Trappes naboby Mortagne i 1689 (Le Nain 1715, 3: 55-58). ${ }^{31}$ Rancé skrev reglementet og definerede både lærerindernes gennemregulerede liv og påklædning og en undervisningsplan, der omfattede læsning, skrivning, matematik, sang og latin. ${ }^{32}$

28. Dictionnaire universel François et Latin, vulgairement appelé Dictionnaire de Trévoux, Nouvelle édition (Paris: La Compagnie les Libraires Associés 1771), 2: 25.

29. Gilles Ménage, Ménagiana ou Les bons mots et remarques critiques (Paris: Chez la Veuve Delaulne 1729) 1: 35-37.

30. Se Jean Mabillon, Traité des études monastiques (Paris: Charles Robustel 1691); Rancé, Réponse au Traité des études monastiques (Paris: François Muguet 1692).

31. Se Chrysogonus Waddell, "The Abbot of La Trappe and the Schoolgirls of Mortagne", Cistercian Studies 24.2 (1989), 127-43.

32. Grundlæggelsesberetningen er trykt i Joseph Besnard, Histoire Religieuse de Mortagne (Mortagne: Imprimerie L. Daupeley 1891), 103-7. En opdateret udgave af 
Endelig tog han imod de mange, der ikke nøjedes med at betragte abbeden og hans regime på afstand, men kom til La Trappe for ved selvsyn at opleve det hårde program. Disse besøg udgør et intenst spændingsfelt, for mens en visit på La Trappe for den besøgende betød tilbagetrækning, var der for munkene tale om et møde med verden, så snart folk gik gennem porten. ${ }^{33}$ Samtidigt var trappisterne ifølge Benedikts Regel forpligtede på at tage imod: ja, gæsterne var ligefrem en prøve i gudskærlighed. ${ }^{34}$ De besøgende skrev beretninger om deres oplevelser. Det er repræsentativt for deres indtryk, når Oratorianeren Claude Masson (d. 1693), som besøgte La Trappe tre dage, begejstret udbryder: "jeg har set alting, og jeg er stadig ikke kommet mig over den forundring, jeg blev kastet ud i af dette store og guddommelige syn". ${ }^{35}$ Den vigtigste beretning var forfattet af kongelig historiograf og medgrundlægger af Académie des Inscriptions et Belles-lettres, André Félibien des Avaux Sieur de Javercy (1619-95). Félibien besøgte La Trappe i $1670 .{ }^{36}$ Han formidlede sine indtryk i Description de L'Abbaye de La Trappe (1671), ${ }^{37}$ som udkom i et handy lommeformat - i nogle udgaver med et foldet kort over La Trappe.

Rancé kommunikerede ivrigt. Hans budskab om radikal isolation blev beundret for dets strenghed, men også for dets retoriske formfuldendthed, og hans pen blev, typisk for tidens lovprisninger af hvem som helst, kaldt en af rigets bedste. Spotterne så Rancés udvekslinger med gæster og adressater som et resultat af forfængelighed

Rancés reglement blev udgivet i 1698: Reglemens pour les filles de la Doctrine Chretienne de la ville de Mortagne (Paris: F. og P. Delaulne 1698).

33. Besøg er et tema, der behandles med stigende intensitet i La Trappes konstitutioner. De tidlige konstitutioner (1671) nævner kun gæster i forbifarten; Anon., Constitutions de l'abbaye de la Trappe (Paris: Michel le Petit og Estienne Michellet 1671), 7. Reglemens generaux fra 1690 har derimod både et eget gæstereglement og en vejledning for de munke, der har ansvar for at modtage gæster; Rancé, Les Reglemens generaux pour l'abbaye de N.D. de la Trappe (Paris: F. Muguet 1701 [1690]), 239-47. I den udbyggede version fra 1698 har reglementet for gæster en prominent plads før de dekreter, der vedhører klosterets forskellige bygninger; Rancé, Les reglemens de l'Abbaye de Nostre-Dame de La Trappe en forme de constitutions (Paris: Florentin et Pierre Delaulne, $\left.{ }^{2} 1698\right), 71-8$.

34. Forpligtelsen er baseret på Jesu ord i Mt 25,35: "For jeg var sulten, og I gav mig noget at spise, jeg var tørstig, og I gav mig noget at drikke, jeg var fremmed, og I tog imod mig" og understreges i Benedikts Regel, kap. 55 og den middelalderlige Ecclesiastica officia, kap. 87 og 120.

35. Claude Masson, Deux retraites de dix jours contenant chacune trente Méditations ... (Lyon: Claude Bachelu 1697), 438: "j’ay tout vû, \& je ne suis pas encore revenu de l'étonnement où m'a jetté un spectacle si grand $\&$ si divin".

36. Se Waddell (1981), 102-161 (129).

37. André Félibien des Avaux, Description de l'abbaye de La Trappe (Paris: Frederic Léonard Imprimeur ordinaire du Roy, 1671); Krailsheimer (1974), 86; Bell (2005), $312 f$. 
og verdslig ambition; hans beundrere talte om næstekærlighed og et gudgivent talent for sjælesorg. Først og sidst er abbedens isolationistiske credo dog i overensstemmelse med tonen i tidens fromhed, og når det fremstår som radikalt, er det først og fremmest, fordi det giver konventionelle temaer ekstra kant. I billedlig forstand er La Trappes mure altså på en gang helt solide og helt porøse. På den ene side isolerer de munkene fra verden og sikrer, at nyheder, livsformer og erindringer holdes ude af deres solitude. På den anden side krydses muren konstant af breve, gæster, billeder, tekster og genstande (kors, skeer, rosenkranse), fremstillet af munkene; alt sammen ting, som er med til at afgrænse og forbinde et fællesskab af fromme mænd og kvinder - munke, nonner og lægfolk - som deler optagetheden af afsondringen fra verden i overensstemmelse med generelle religiøse mønstre, som præger Frankrig i slutningen af 1600-tallet. Rancé var genkendelig qua baggrund, uddannelse og religiøs horisont; men hans livsvalg og den kompromisløshed, hvormed han gennemførte det, skilte ham ud.

\section{Rancés program}

Afhandlingens tredje og længste del, Topoi, analyserer Rancés asketiske program (Bruun 2017, 387-752). Målet med trappistmunkens liv var at nedbryde det jordiske selv til fordel for et selv vendt mod Gud. Grundtanken er klassisk, og realiseringen af den er målet for klosterbevægelsen. Men ideen om, at mennesket skal nedbryde sig selv og derpå absorberes fuldstændigt i enhed med Gud gennemstrømmer også tidlig moderne fransk fromhed, hvor den skærpes af tidens forkærlighed for prægnant sprog og suggestive billeder. Ørkenfædre og -mødre blev moderne allerede fra slutningen af 1500-tallet, hvor de flamske Sadeler-brødre udgav populære og rigt udstyrede samlinger af ørkenportrætter, ${ }^{38}$ og Rancés samtidige slugte de mange udgaver af Les vies des Saints Peres des deserts et de quelques saintes (fra 1647). Ja, Mme de Sévigné beskriver ligefrem, hvordan en kvinde blev så betaget af ørkenfædrene, at hun satte afsted mod Indien for at gøre dem kunsten efter, men blev stoppet af familien i Rouen. ${ }^{39}$ Selv Rancés be-

38. Leopoldine van Hogendorp Prosperetti, "Helenus and Dorotheus: Marten de Vos and the Desert Fathers", Imago Exegetica: Visual Images as Exegetical Instruments, 1400-1700, red. W. Melion, J. Clifton \& M. Weemans (Leiden: Brill 2014), 423-48.

39. Brev fra Mme de Sévigné til Charles de Sévigné af 5. august 1684; Madame de Sévigné: Lettres, red. Émile Gérard-Gailly, 3 bd. (Paris: Gallimard 1953-57), 2: 
mærkelsesværdige tanke om den sandt troendes fuldstændige hengivelse til Gud som et brændoffer (holocauste), findes også hos François de Sales (1567-1622), som i 1600-tallets første årtier anslog tonen for den lægmandsfromhed, der prægede le grand siècle. ${ }^{40}$ Det, der er særligt for Rancé, er at han lader den radikale tale udmønte i et praktisk program. Han fremlagde programmet i sine monastiske skrifter, men det blev først og fremmest formidlet til omverdenen i hans breve til lægfolk, munke og nonner og i de populære trappistbiografier, som præsenterede udvalgte munkes omvendelse og personifikation af klosterets idealer. ${ }^{41}$

Rancés program er bygget op omkring en række komponenter, som hver har et kapitel i afhandlingen: omvendelse, afsondring, tavshed, disciplin, bod, ydmyghed, bøn og kærlighed. Deres indbyrdes forbundethed betyder, at analysen af eksempelvis bøn egentlig allerede begynder i kapitlet om omvendelse, ligesom undersøgelsen af tavsheden først sluttes med kapitlet om kærlighed. Her skal vi koncentrere os om afsondringen som den komponent, der er mest særegen for Rancés reform, og dykke ned i abbedens særlige tone og argumentationsform.

\section{Sted}

For Rancé er solitude den linse, alt ses igennem. Lidt skematisk kan begrebets facetter samles i tre overordnede temaer: solitude er et sted (ørken, ødemark), en tilstand (isolation og skjulthed) og en strategi for handling (forsagelse af verden). Som sted er solitude det modsatte af hoffet og byen, og Rancés begreb om solitude får en væsentlig del af sin semantiske vægt i kraft af dets funktion som en negation af le monde, verden. Konkrete afsværgelser af Paris eller Versailles er sjældne i Rancés skrifter. I stedet anvender han bredere allusioner til "verden" som kilden til alt ondt (Rancé 1683, XI.6, 1, s. 308), mens han ærgrer sig over, at "enhver i verden ikke stræber efter andet end at hævde sig og vinde hæder, og det er primært det, man bygger hele sit liv på; man søger ære, og man vil have den, ligegyldigt hvor høj prisen er" ${ }^{\prime 2}$ (Rancé 1689 , 1, s. 390). Abbeden fortaber sig imidlertid

\section{2-53.}

40. Se fx François de Sales, Traicté de l'amovr de Diev (Lyon: Pierre Rigaud 1617 [1616]), 422 .

41. Se M.B. Bruun, "Hertugindens Bøger: Noter vedrørende Mme de Guises afregning hos Élie Josset (1693-96)", Teologien i Historien - Historien i Teologien, red. C. Selch Jensen \& C. Gottlieb (København: Eksistensen 2016), 195-214 (209-11). 42. "chacun ne tend dans le monde qu'à s'élever \& à se donner de la distinction; c'est à cela principalement qu'on rapporte tout l'état de sa vie; on recherche de la gloire, $\&$ on en veut avoir à quelque prix que ce soit". Dette "on" indbefatter også et "vi". 
ikke i beskrivelser af de jordiske udskejelser, men opregner i stedet de mangfoldige måder, hvorpå verden binder sine borgere til en selvkærlighed, der leder dem væk fra dydens smalle sti. Rancé er ingen Savanarola; han fordømmer ikke verden, men begræder, at den er så - verdslig.

Alternativet til verdslighed er tilbagetrækning. I de monastiske værker synes Rancé at forudsætte, at munken kan afsondre sig fuldstændigt fra verden ved at flytte sig fysisk. I tilbagetrækningen udvisker Gud - ideelt - munkenes tidligere liv fra deres hukommelse, og Rancé kan beskrive modsætningen mellem verden og tilbagetrækningen som en endegyldig overgang til et nyt liv:

Gud har opløst alle disse forhindringer, og han har bevaret jer fra alle former for fristelse, idet han trak jer tilbage til la solitude. Hvad verden angår, lever I, som om den ikke længere fandtes; den er slettet fra jeres erindring, ligesom I er slettet fra dens (Rancé 1683, VII.2, 1: 139). ${ }^{43}$

Solitude er det sted, hvor afsondringen udspilles, og i første omgang er dét sted La Trappe. ${ }^{44}$ Videre er solitude imidlertid synonymt med den ørken, som har tiltrukket munke gennem århundreder, og Rancé åbner andet bind af De la sainteté med en erklæring om, at ørkenen altid har været himlen for de sande solitaires (Rancé 1683, XVI.1, 2: 4). Solitaires er en teknisk term for munke, men i modsætning til synonymer som religieux eller moines, gælder ordet det rette, afsondrede munkeliv, som kun er få beskåret.

Men til syvende og sidst er heller ikke ørkenen fri for fristelser. Selv den oprindelige paradisiske ørken gik tabt, da ørkenfæd rene slækkede på deres lydighed over for Guds bud. Deres fald blev ikke overraskende forårsaget af typiske monastiske laster som nysgerrighed og rastløshed, og Rancé udpensler, hvordan formålsløse samtaler hensatte dem i en tilstand af åndsfraværende dvaskhed; selv deres forhold til den opbyggeligt barske natur blev efterhånden til blødsøden magelighed:

De begyndte at løbe fra ørken til ørken, fra bjerg til bjerg, fra grotte til grotte, drevet af deres uro og under et falsk fortegn om at ville søge opbyggelse i samtaler med deres brødre; de byggede ... deres celler ved flodbredden imod de gamles råd og instruktioner, og de plantede træer

43. "Dieu vous a levé tous ces obstacles, \& vous a preservez de ces sortes de tentations, en vous retirant dans la solitude. Vous estes, à l'égard du monde, comme s'il n'estoit plus; il est effacé dans vostre memoire, comme vous l'estes dans la sienne ...”. 44. Se fx Conference faite le I. Dimanche d'après Pasques i Rancé (1698), 2: 352. 
for at skærme sig mod solen. Kort sagt forlod de deres fædres snævre veje og gjorde sig nye veje, der var brede og rummelige ... . ${ }^{45}$

Efter dette fald viser ørkenen sit diabolske ansigt. Den er ikke længere et åndeligt frugtbart sted, men en dæmoniske ødemark hjemsøgt af onde kræfter og endegyldigt forladt af Gud (ibid., 34-35). På trods af det kuldsejlede ideal, bevarer ørkenen sin ætiologiske kraft og ørkenmunkene deres asketiske strålekrans som Kristi soldater - "Disse åndelige krigere fører deres krig ved at beskæftige sig med deres forskellige opgaver, inspireret og drevet af en og samme ånd, synger nogle af dem Salmerne, mens andre beder, nogle skriver, og nogle er optaget af fysisk arbejde." ${ }^{46}$

Rancé sammenligner ofte sin trappist-reform med livet i den oprindelige ødemark. Han fremskriver en form for samtidighed mellem bibelens ørkener, Theben og La Trappe, som forstærkes yderligere gennem klosterets udsmykning. Bibelske og patristiske sentenser på væggene alluderer til forskellige former for solitude, og ørkenhelgenen Maria af Egypten æres i et alter, Rancé får bygget som led i en omfattende renovation af klosteret. Det kan virke sært, at munke tager en af den hagiografiske litteraturs mest flamboyante omvendte skøger som deres eksempel, men Maria af Egypten fungerer som en radikaliseret udgave af Maria Magdalene - tidens foretrukne model for bodfærdig begrædelse af fortidens synder. ${ }^{47}$ Når den slags associationer

45. II. Conference pour le dimanche de Septuagesime i Rancé (1698), 2: 36f: "ils en ont eû de curieuses $\&$ d'inutiles, qui les ont jettez dans la langueur $\&$ dans la dissipation; ils ont couru de desert en desert, de montagne en montagne, de caverne en caverne, emportez par leur inquietudes sous de faux pretextes de chercher de l'édification dans l'entretien de leurs Freres; ils ont bâti ... des cellules sur le bord des fleuves, contre les instructions $\&$ les avis des anciens; ils y ont planté des arbres pour se deffendre des ardeurs du Soleil: Enfin ils ont quitté les voies de leurs Peres, qui étoient étroites, \& s'en sont fait de larges \& de spatieuses ...."

46. Rancé, Eclaircissemens de quelques difficultez que l'on a formées sur les livre de sainteté et des devoirs de la vie monastique (Paris: François Muguet 1685), 411f: "Ces Combatans spirituels font leur guerre, lorsqu'en s'occupant à leurs divers offices par les mouvemens \& la conduite d'un mesme esprit, les uns chantent les Pseaumes, les autres prient, les autres écrivent, les autres se fatiguent dans les travaux corporels ...."

47. Dominique Georges, "Procès Verbal de l'état spirituel \& temporel de l'Abbaïe de la Trappe" i Pierre de Maupeou, La vie du très-reverend père Dom Armand Jean Le Bouthillier de Rancé, 2 bd. (Paris: L. d'Houry 1602 [i.e. 1702]), 2: 251-76 (270); Fr. Pacôme, Description du plan en relief de l'Abbaye de la Trappe presenté au Roy par le Frere Pacôme (Paris: Jacques Collombat 1708), 70f; se desuden Mette Birkedal Bruun, Sven Rune Havsteen, Kristian Mejrup, Eelco Nagelsmit \& Lars Nørgaard, "Withdrawal and Engagement in the long Seventeenth Century: Four Case Studies", Journal of Early Modern Christianity 1.2 (2014), 249-343 (271). 
fremmanes, er det ikke alene ørkenens sted, men også dens tilstand af selvforsagende askese, der aktiveres.

\section{Tilstand}

La Trappes solitude er på én gang skjult og synlig. Folk, der besøgte klosteret, fortæller, hvordan dets placering i landskabet gjorde, at skove og bakker skjulte det (Félibien 1871, 6), men samtidigt er det på et andet plan stillet til skue for verden. Før Rancés ankomst, fortæller en samtidig hagiograf, var synligheden smertelig, og klosteret var en skandale for hele omegnen, men nu, efter reformen, er klosteret "genstand for hele kristenhedens beundring" ${ }^{48}$ Rancé understreger selv, hvordan munkene, som alle følgere af Benedikts Regel, udøver deres askese for øjnene af Gud og abbeden, men også under verdens blik. Under denne intense granskning kan de ikke være for opmærksomme på, hvordan de tager sig ud, og Rancé opridser et skræmmende scenarie for sine læsere: "Vil I, mine brødre, virkelig have, at vi i jeres personer viser verden en form for monster eller kimære, der kombinerer to ting, der er så forskellige og så modsatrettede som den deforme blanding af en slet reguleret fremtoning og et aflagt løfte om hård bod?" 49

Klosterets eksponering tjener til opbyggelse, og munkene spiller, ifølge Rancé, en samfundsmæssig rolle som forbilleder. Men rollen er smertelig, for munkene afsoner verdens synd i efterfølgelse af Kristus, og ligesom præsten holder op med at være synder, i det øjeblik han bliver præst, på samme måde

ophører en retfærdig med at være retfærdig i det øjeblik, han bliver munk, og han kan herefter udelukkende betragtes som en synder. Han taber sin uskyld, idet han lukker sig inde i klosteret, på samme måde som Jesus Kristus på sin vis holdt op med at være hellig, i det øjeblik han viste sig i verden i en synders form og fremtoning, ikke bare for menneskers betragtning, men også i den strenge behandling, hans fader underkastede ham (Rancé 1683, XII.21, 1, s. 392-93). ${ }^{50}$

48. A. d'Arnaudin, La vie de Dom Pierre le Nain, religieux et ancien souprieur de l'Abbaye de la Trappe (Paris: Saugrain l'aîné 1715), 18f: "le sujet de l'admiration de toute la Chrétienté".

49. Conference pour le III. Dimanche après les Rois i Rancé (1698), 1: 322f: "Voudriez-vous, mes Freres, que l'on fît voir au monde, en vos personnes, une espece de monstre, ou de chimere, en alliant deux choses aussi differentes $\&$ aussi contraires, que la difformité d'une contenance mal reglée, \& la profession d'une penitence severe?"

50. "un juste cesse d'estre regardé comme juste, dans le moment qu'il est Moine, et il ne peut plus estre regardé que comme un pecheur: Il perd son innocence en se renfermant dans le Monastere, de mesme que JESUS-CHRIST a cessé en quelque 
Rancé opholder sig ved den nådesløse udstillelse: pénitent public, être regardé, se faire voir dans le monde. Munken soner synder, han ikke nødvendigvis selv har begået. Det, at han bliver set, er en del af hans bod, men blotlæggelsen er samtidig en katalysator for effekten af denne bod: den tjener til andres omvendelse.

Munkene er elitetropper, som absorberer synden, men for gæsterne er klosteret en fredelig havn, og Rancé forklarer, at det skal være synligt for at kunne tiltrække dem, som ellers er i fare for at lide skibbrud og gå til grunde i verden. Munkene er som fyrtårne, der leder skibene sikkert i havn (Rancé 1685, 454-55). De utallige gæster på La Trappe var en udfordring, men de bekræfter samtidig, at klosteret lever op til sin funktion som et tilflugtssted fra verden. I deres tilbagetrækning er munkene en ledestjerne, og de kan ikke lade den essentielle skjulthed gå ud over deres synlighed. Paradokset er tydeligt, og Rancé har ikke travlt med at opløse det: La Trappe kan kun fungere som et symbol på isolation, der tilskynder til efterligning, hvis det bliver set og besøgt.

\section{Strategi}

Solitude er en negation. Som den sidste betydning, skal vi her kort opholde os ved solitude som den ideelle afsondringsstrategi, markeret ved det benægtende "de-" og det regressive "re-". Den sande kristne er dégagé og détaché (Rancé 1683, I.3, 1: 3), og munken forstærker denne adskillelse: han har renoncé (ibid., I.2, 1: 2) og befinder sig i en desoccupation entiere de toutes les choses du monde (ibid., II.2, 1: 7). Frasen se retirer $d u$ monde er besnærende ligefrem, men hvad er det, trappisterne trækker sig tilbage fra? "Le monde", verden, kan betegne det samtidige franske samfund, livet uden for murene og verdslighedens ånd, og betydningen af tilbagetrækningen fra den er tilsvarende forskelligartet.

Det gensidigt ekskluderende forhold mellem le monde og la solitude tematiseres ofte hos Rancé. Men både hans prædikener og breve er også rige på advarsler om verdslige laster, der sniger sig ind i klosteret, og når abbeden beklager, at verden (le monde) er fuld af personer, som lever som slaver af deres lidenskaber, er munkene ikke undtaget. ${ }^{51}$ Faktisk afslutter munkene den liste over farer, som plager hver stand i samfundet, og skønt munkene adskiller sig fra verdslige personer (des personnes $d u$ monde) ved deres øvelser og beskæftigelse, er de alt for ofte drevet af de samme drifter og mål (Rancé 1689, 1: 306). Samti-

sorte, de passer pour Saint au moment qu'il s'est fait voir dans le monde avec l'habit, $\&$ et sous la forme d'un pecheur, non seulement dans l'opinion des hommes; mais encore dans les traitemens rigoureux qu'il a receus de la main de son Père”.

51. Conference pour le III. Dimanche après les Rois i Rancé (1698) 1: 319. 
digt har munkene ifølge Rancé givet afkald på nogle af de verdslige former for anstændighed, som hjælper samfundets øvrige borgere til at føre et retskaffent liv. Det gælder ikke mindst den i samtiden lovpriste dyd: honnêteté, det svært-oversættelige begreb om en socialt og identitetsmæssigt kultiveret adfærd, som dækker alt lige fra hofetikette til samfundsmoral. ${ }^{52}$ Hermed tilføjes endnu en dimension til Rancés forståelse af solitude, som altså også er et sted og en tilstand, hvor munkene konfronteres med farer uden at være beskyttet af civilisationens egne modforanstaltninger.

Rancé er ikke poetisk. Men en af hans mest lyriske passager omhandler solitude, og den gælder stedets betydning for genoprettelsen af den paradisiske harmoni. Parafraseret er det her, mennesket reparerer sjælens billede af skaberen, som var udvisket af synden; det er her, det vender tilbage til sin oprindelses renhed, hvor det genfinder sin fornufts kraft og bortvejrer de skyer, som formørkede den, og hvor den korrumperede natur endelig genfinder sin første uskyld. "Oh Solitude! Du er lasternes ødelæggelse”. Her modtog Moses de ti bud, her oplevede profeten Elias Guds nærvær. "Solitude, du er Jakobs stige, som giver menneskerne adgang til at stige op til himlen og englene til at stige ned til menneskerne. En kort genvej til frelsen". Det er her, vi ser os selv uden smigrende omsvøb og korrigerer sjælens mest skjulte og hemmelige fejl. Her kan vi tale med Gud uden afbrydelse, modtage hans råd og lytte til den indre stemme, som han taler til sjælene med, uden at sanserne har noget at skulle have sagt (Rancé $1685,406-07) .{ }^{53}$

52. Conference pour le 1. Dimanche de l'Avent i Rancé (1698), 1: 13.

53. Citatet lyder i sin helhed: "bien-heureuse Solitude, dans laquelle l'homme repare dans son ame l'image de son Createur qu'il voit effacée par le peché; dans laquelle il retourne à la pureté de son origine, dans laquelle il recouvre la vivacité $\&$ la vigueur de sa raison, en la dégageant des nuages qui l'avoient obscurcie; $\&$ où enfin la nature corrompuë, retrouve en quelque sorte son integrité, \& sa premiere innocence ... O Solitude! tu es la ruine des vices, \& l'établissement des vertus, \& tous ceux qui sont arrivez à quelque perfection, connoissent combien tu es digne de loüanges! C'a esté dans la solitude que Moïse a receu par deux fois le Decalogue pour le donner au Peuple de Dieu: C'a esté dans la solitude que le Prophete Elie a joüi de la presence de Dieu, qu'Elisée a receu le double esprit de son Maître, \& le Sauveur du monde a voulu que son Precurseur vécût dans la separation du monde. Solitude, tu es cette échelle de Jacob qui fais monter les hommes jusques dans le Ciel, \& qui fais descendre les Anges vers les hommes pour les secourir. La Solitude est une voye courte $\&$ abregée pour le salut: C'est un état dans lequel on voit $\&$ on corrige, sans se flatter, les défauts les plus secrets \& les plus cachez de son ame, $\&$ dans lequel on a toûjours la liberté de s'entretenir avec Dieu, de le consulter, de l'écouter sans estre interrompu, de recevoir ses conseils, d'agir par sa conduite \& par sa sagesse, d'entendre ce langage interieur avec lequel il parle aux ames, sans que les sens y ayent la moindre part." 
Solitude er et bibelsk sted, en genvej, en stige, en tilstand. Det er der, det mest intime møde med Gud og den mest målrettede udslettelse af synd finder sted. Netop fordi solitude er en form for intethed, kan den være alle disse ting. Også på dette niveau er grænsen mellem kloster og verden på én gang robust og fleksibel. På den ene side er munkene i konstant fare for at blive overtaget af verden, på den anden side kan mennesker uden for klosteret få del i det potentiale, der ligger i solitude, og som Rancé i sin korrespondance søger at bringe videre.

For Rancé er le monde og la solitude ikke blot steder, men også sindelag og eksistentielle strategier. Det afsondrede sindelag kan trives på begge sider af klostermuren, men har de bedste vilkår indenfor. At solitude ikke kun er tilgængelig i solitude kaster lys over den tilsyneladende kollision mellem abbedens fordring på solitude og hans omfattende korrespondance. Sandsynligvis mente Rancé ikke, at han engagerede sig i verden gennem sine breve, fordi det diskursive rum, han her træder ind i, ikke er verdens, men det afsondrede, solitære sindelags.

\section{Epilog}

Udvekslingen mellem afsondring og engagement er på en gang helt umulig og helt grundlæggende. Hvis vi kun ser på Rancés værk, er der ingen tvivl om, at han insisterer på isolation, og set i det lys er strømmen af breve og gæster i bedste fald forvirrende. Men hvis vi undersøger hans tekster $\mathrm{i}$ et bredere perspektiv og holder dem sammen med hans korrespondance og trappisternes pligtskyldige gæstfrihed, begynder vi at se, at hans idé om tilbagetrækning fra verden var tæt knyttet til hans dobbelte opfattelse af, at Kristus er til stede i næsten, og at hans sjælesorgsforpligtelse rakte langt ud over opgaverne som abbed. Endelig må vi, hvis vi vil forstå hans interaktion med verden uden for klosteret, tage hans biografi i betragtning. De cirkler, Rancé færdedes i, før han blev munk, hans families netværk og hans venskaber med biskopper er alle faktorer, der spiller ind i Rancés syn på tilbagetrækning og engagement.

Hvorfor bruge så mange kræfter på en abbed i 1600-tallets Frankrig? Ud over at være et fascinerende fremmed fænomen påkalder Rancé sig opmærksomhed som en nøgle til tidlig moderne fransk fromhed, som i nogen grad er et overset forskningsfelt. Derudover giver hans asketiske program i dets kirke- og kulturhistoriske kontekst rig lejlighed til at studere modulationerne i en bestemt version 
af den monastiske tilbagetrækning fra verden. For Rancé er retraite og solitude både absolutte og fleksible. Paradokset må ikke opløses og spændingen ikke nedtones. Abbedens begreb om solitude er betingelsesløst, og tilbagetrækningen fra verden må ske uden den mindste reservation. Men fordi det begreb om "verden", som negeres i tilbagetrækningen, har mange facetter, bliver begrebet om solitude også plastisk. I sin kalibrering af solitude håndhæver Rancé kravet om afsondring fra verden på en måde, som gør ham tidstypisk og genkendelig for samtidens fromme mænd og kvinder. Men i den kompromisløse afsondring, han afkræver de asketisk elitære trappister, er han samtidig ualmindeligt radikal. 